\title{
EXPERIMENTAL INVESTIGATION ON AN EXHAUST EMISSION CHARACTERISTICS OF A COMPRESSION IGNITION ENGINE FUELED WITH DIESEL-WATER EMULSION
}

\author{
Abdulrahman Shakir Mahmood ${ }^{1}$ \\ abdoww79@yahoo.com
}

\author{
Haqi I. Qatta ${ }^{2}$ \\ haas99009@gmail.com
}

\author{
Saadi M. D. Al-Nuzal ${ }^{3}$
}

saadidhaher@yahoo.com

1,3 Environmental Research Center, University of Technology, Baghdad, Iraq.

${ }^{2}$ Nanotechnology And Advanced Materials Research Center, University of Technology, Baghdad, Iraq.

\begin{abstract}
One of the main sources of global air pollution is the undesirable gas emissions from diesel engines, as well as the accompanied particulate matters (PM). Consequently, the reduction of their amount and quality is highly recommended for clean environment. The present work includes an attempt to use diesel-water emulsion as a fuel on compression ignition (CI) engine emissions and to investigate its effect on these hurtful discharges. For this reason, tests are carried out on a single cylinder, 4-stroke CI engine with steady speed (1500 rpm) and different loads (0-100\%) operated with various proportions of diesel-water emulsions and compared it to the diesel fuel. Four samples of diesel-water emulsions are prepared at ratios of $(5,10$, 15 and $20 \%$ ) by water volume in diesel and with help of Tween 20 and Oleic Acid as a surfactant to maintain its stability for long periods of time. Gas emissions of the engine are recorded for $\mathrm{CO}_{2}, \mathrm{CO}, \mathrm{HC}$, and $\mathrm{NO}_{\mathrm{X}}$ using an exhaust gas analyzer and smoke opacity using a device of smoke meter. Results reveal that the diesel-water emulsion significantly decreases the $\mathrm{NO}_{\mathrm{X}}$ emissions and smoke opacity. The highest reduction ratio for $\mathrm{NO}_{\mathrm{X}}$ and smoke opacity are found in case of fuel emulsion DW20, with values of $32.5 \%$ and $39 \%$ respectively, in comparison with that of diesel fuel.
\end{abstract}

Keywords: CI engine, diesel-water emulsion, NOx emission, smoke opacity

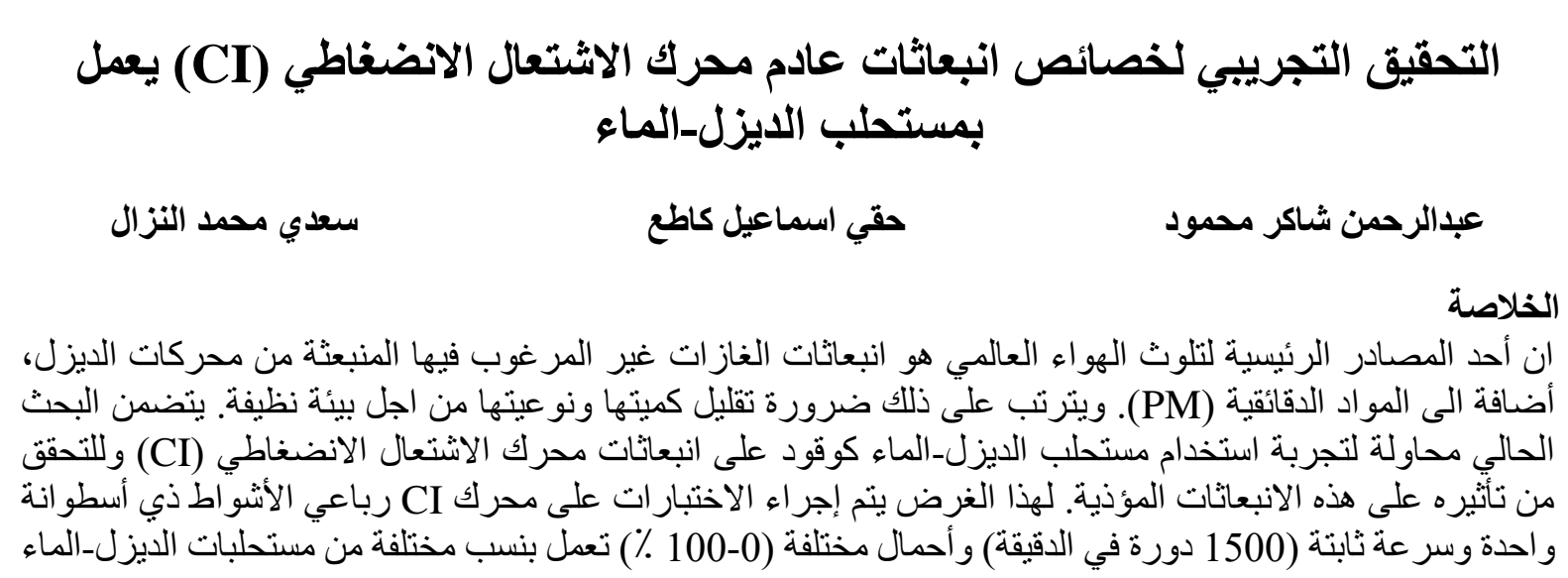

Received:26-1-2020

Accepted: 
ومقارنتها بوقود الديزل. تم تحضير أربع عينات من مستحلبات الديزل-الماء بنسب (5 ، 10 ، 10 ، 15 و20 \%) من حجم الماء

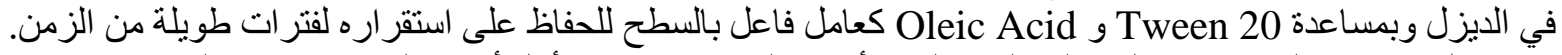
تم تسجيل انبعاثات الغاز ات من المحرك بالنسبة لثاني أكسبد الكاربون CO

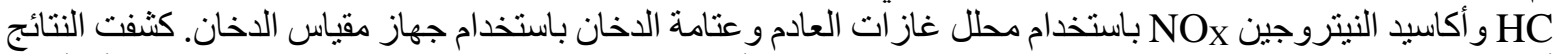

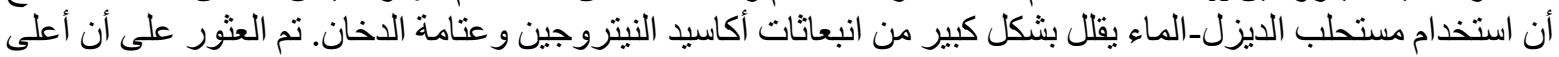
نسبة تخفيض لأكاسيد النيتروجين وعتامة الدخان تحصل عند استخدام مستحلب الوقود \% على التو الي، مقارنة مع وقود الديزل.

\begin{tabular}{ll}
$\begin{array}{l}\text { NOMENCLTURE } \\
\text { Latin Symbols }\end{array}$ & \multicolumn{1}{c}{$\begin{array}{c}\text { Description } \\
\text { brake specific fuel consumption }(\mathrm{kg} / \mathrm{kW} . \mathrm{sec})\end{array}$} \\
$\mathrm{BSFC}$ & compression ignition \\
$\mathrm{CI}$ & carbon monoxide $(\% \mathrm{Vol})$ \\
$\mathrm{CO}$ & carbon dioxide $(\% \mathrm{Vol})$ \\
$\mathrm{CO}_{2}$ & direct injection \\
$\mathrm{DI}$ & diesel-water emulsion \\
$\mathrm{DW}$ & unburnt hydrocarbons $(\mathrm{ppm})$ \\
$\mathrm{HC}$ & hydrophilic - lipophilic balance \\
$\mathrm{HLB}$ & nitrogen oxides (ppm) \\
$\mathrm{NO}$ & polycyclic aromatic hydrocarbon \\
$\mathrm{PAH}$ & particulate meters \\
$\mathrm{PM}$ & parts per million \\
$\mathrm{ppm}$ &
\end{tabular}

\section{INTRODUCTION}

The kinetic energy of the fuel obtained from various engine types was originated from its potential chemical energy. Diesel engines find wide applications in power generation sector in Iraq as well as in transportation, agriculture and industrial sector Hegde et al. (2016). No wonder for that, for it has sound economical consumption of fuel as well as having greater power and higher efficiency compared with that of gasoline engine Seifi et al. (2016). Unfortunately, some harmful emissions of environmentally unrecommended gases were emitted, among them were; $\mathrm{NO}_{\mathrm{X}}, \mathrm{CO}, \mathrm{CO}_{2}, \mathrm{HC}$ and smoke, which were formed through the combustion process Jiaqiang et al. (2016). The emissions of $\mathrm{NO}_{\mathrm{X}}$ and smoke were responsible for the main sources of air pollution, and can cause serious harms to humans, animals, plants and environment Mondal and Mandal (2019). A helpful alternative for these unwanted emissions is highly needed to improve the performance and for mitigation purposes by the environmentalists. The emulsions of diesel-water can be considered as an alternative to reduce the emission of $\mathrm{NO}_{\mathrm{x}}$ and smoke simultaneously, provided that there will be no significant modifications to the engine Ithnin et al. (2014). The provided explanation is based on the fact that steam generated from water will absorb the produced combustion heats, which consequently decrease the flame temperature accompanied by $\mathrm{NO}_{\mathrm{x}}$ and smoke emissions reduction Şahin et al. (2014), Marchitto et al. (2018). Many articles appeared in the literature that deals with the mixing the basic diesel fuel with biodiesel, alcohol, gasoline, water, or other materials. Paul et al. (2017), Pongamia piñata methyl esters (PPME) at proportion of 50 $\%$ and $5-20 \%$ ethanol blend was used in a diesel engine to comparative and evaluate the engine performance. Results showed that a blend of $50 \%$ PPME, $15 \%$ ethanol and $35 \%$ diesel fuel has two major effects on the engine performance through the reduction of fuel consumption as well as increasing its thermal efficiency. Kannan and Anand (2011), a series of experiments were conducted using diesel, biodiesel and biodiesel - diesel - ethanol 
(diestrol) water micro emulsion as a fuels to evaluate the performance, emission and combustion characteristics of the diesel engine at different loads and constant speed of 1500 $\mathrm{rpm}$. It was found that the brake specific fuel consumption (BSFC) for biodiesel and micro emulsion fuels were higher than that of diesel alone, and the emission characteristics $(\mathrm{CO}$, $\mathrm{CO}_{2}, \mathrm{HC}$ and $\mathrm{NO}_{\mathrm{X}}$ ) were lower than that those of diesel fuel at all loads. Also found the heat release rate was higher compared with the biodiesel and diesel fuels for all loads. Lin et al. (2011), in another experiment, polycyclic aromatic hydrocarbon (PAHs) as well as PM were emitted from n-butanol combustion in blend of diesel fuel-butanol-water emulsion. It was found that increasing the proportion of n-butanol reduced the PM emissions and PAHs, but at the same time increased the CO emissions and fuel consumption. Salih (2017), the effect of water proportion in the diesel emulsion on diesel engine was studied, reveals that $20-30 \%$ of the water volume improves the engine performance and reduces the emissions. Alahmer et al. (2010), a series of experiments was carried on a diesel engine to evaluate the performance and emissions at speed range from 1000 to $3000 \mathrm{rpm}$, using diesel with 5 to $30 \%$ water emulsion blends. The results indicated a decrease $\mathrm{NO}_{\mathrm{X}}$ emissions and significant improvement in fuel consumption and thermal efficiency. Ochoterena et al. (2010), Combustion properties and spray behavior of diesel-water emulsion was studied and concluded that such emulsion lead to a lower soot formation as well as slight ignition delay. Dubey and Saxena (2016), when a set of 10-30\% emulsions were used; it improved the performance and significantly reduces the emissions of $\mathrm{NO}_{\mathrm{X}}$ and PM. Scarpete et al. (2013), attempted to evaluate agricultural tractor engine at different loads and speeds, and found that engine torque decreased on increasing water content. This was explained on the bases that lower heating value of the emulsion, accompanied by less $\mathrm{NO}_{\mathrm{X}}$ emissions, but unfortunately associated with an increase in CO. Syu et al. (2014), The performance and emissions of a light-duty diesel engine generator was evaluated using different proportions of diesel-water emulsion $(0-15 \%$ of water content), and found an increase in thermal efficiency by 1.2-19.9 $\%$, and a decrease of $\mathrm{NO}_{\mathrm{X}}$ by $18.3-45.4 \%$. In this study various emulsion blends of dieselwater in the range of 5-20\% (water volume) with the help of commercially available Tween 20 surfactant will be analyzed. A compression ignition engine will be run at different loads ( 0 - $100 \%$ ) and constant speed $1500 \mathrm{rpm}$ by using these emulsions, and the amount of various gases emissions will be recorded. A comparative discussion concerns the relation between these variables and the obtained gases emission is to be made.

\section{METHODS AND EXPERIMENTS}

\section{Diesel - Water Emulsions}

Throughout this work, diesel-water emulsions are prepared by mixing various volumes of the two immiscible components, and bring them into emulsion by using an emulsifier. The used emulsifier is a surfactant. In this case the dispersed material is water, and the main component is the diesel as the continuous phase, as oil in water or water in oil Alahmer et al. (2010). The components of the emulsifier are distilled water, diesel fuel which contains the Cetane Index 48 and a surfactant material (Tween 20 and Oleic Acid). The emulsion fuel is prepared by mixing the surfactant materials together by $0.5 \%$ for each type to obtain the HLB, after that, these materials are added and mixed with pure diesel fuel by (79 to $94 \%$ ) using a mechanical mixer for 20-25 minutes at $3000 \mathrm{rpm}$, finally, the distilled water by (0 to $20 \%$ ) is added gradually with efficient mixing at ambient laboratory temperature. The stability requirements for the obtained emulsions are to keep the emulsion stable for few days at wide degrees of temperatures Hasannuddin et al. (2014). Considering that the injected fuel emulsion will last for a while in transfer fuel pipes before it is injected inside combustion chamber, the stable 
emulsion will not separate before entering the combustion chamber Dibofori-Orji (2011). In the present work, four emulsified fuel blends are prepared in the following proportion; 5,10 , 15, 20 water percentage and designated as DW5, DW10, DW15 and DW20 respectively, as shown in table (1).

The physical properties of these emulsions and pure diesel like density, calorific value and viscosity are determined, and presented in table (2). The density are determined using hydrometer; Calorific value using analyser type - P6310 - Bomb Calorimeter and kinematic viscosity using viscometer type - VR 3000 MYR Viscometers, respectively. The results presented in table (2) reveals that an increase in the density and viscosity of the emulsion fuel as well as a reduction of the heating value compared to pure diesel fuel.

\section{Experimental Setup}

A single cylinder, 4-stroke, water-cooled direct injection CI engine is used to conduct the experiment needed to judge the best water content among these emulsion fuels. The engine specifications are described in table (3), and the schematic diagram of the experimental setup is illustrated in figure (1). The engine is connected with a rope brake dynamometer as a loading device. The exhaust is supplied with gas emission analyzer device of the type (AVL DIGAS 444) to measure the emissions of unburned hydrocarbons (HC), carbon dioxide $\left(\mathrm{CO}_{2}\right)$, carbon monoxide $(\mathrm{CO})$ and nitrogen oxides $\left(\mathrm{NO}_{\mathrm{X}}\right)$, as well as the smoke opacity is measured using the device of smoke meter of the type (AVL 437C), both supplied by Avl India Private Limited, India.

\section{Experimental Procedure}

Before starting the tests, the probes of the exhaust gas analyzer and smoke opacity meter are installed inside the engine exhaust port. Then the engine operated initially with diesel fuel at a speed of $1500 \mathrm{rpm}$, and then the loads are increased from 0.0 to 12.5, 25, 50, 75 and $100 \%$ by a rope brake dynamometer. When the engine reaches to a steady state, the gas emission constituents are recorded and for every $10 \mathrm{ml}$ consumption of the fuel. For every load, the test is repeated twice to obtain the average optimum values. The fuel tank is drained out of its content, and it is then filled with samples of emulsion fuels (DW5, DW10, DW15 and DW20), and the same of the above steps are followed for every sample of diesel-water emulsion fuels.

\section{RESULTS AND DISSECTION}

The tests mentioned in the experimental part conducted on the CI engine using a pure diesel and four samples of diesel-water emulsion fuel designated DW5, DW10, DW15 and DW20. The emissions of $\mathrm{NO}_{\mathrm{X}}$, smoke, $\mathrm{HC}, \mathrm{CO}$ and $\mathrm{CO}_{2}$ were recorded and presented in figures (26 ), and the results were discussed in the following paragraphs as indicators for the validity of the engine in concern with the environment pollution. figure (2), concerned with recording the emissions of $\mathrm{NO}_{\mathrm{X}}$ for the above-mentioned emulsions compared to that of the only diesel fuel case. It is apparent that the $\mathrm{NO}_{x}$ emission increases on increasing the loads, for all the types of fuels. Possibly this observation can be related to the increase of the cylinder temperature when the engine loads increase Mahmood et al. (2019). It worth to mention that there are significant decrease in the amount of the emitted $\mathrm{NO}_{\mathrm{X}}$ for the emulsions fuels compared to diesel only fuel, where it decreased by 11.1, 17.67, 25.8 and $32.5 \%$ for DW5, DW10, DW15 and DW20, respectively. An explanation for this phenomenon is to relate the formation of steam inside the engine cylinder as a result of high temperatures, this steam was generated from water will absorb the produced combustion heat, which consequently decrease the flame temperature, hence decrease the emission of $\mathrm{NO}_{X}$ Marchitto et al. (2018). Similarly, 
the values for a smoke opacity emitted from fuel of diesel-water emulsions and only diesel fuel versus load were recorded and plotted in figure (3). From the figure, it is possible to observe a similar behavior to that of $\mathrm{NO}_{\mathrm{X}}$; viz. the property is directly proportional with the applied load on the engine. In the same words the intensity of the smoke opacity increased on increasing the loads. Smoke formation is related to a lack of air amount inside cylinder and oxygen content in the fuel, which is reflected with incomplete combustion of the fuel. Also from the figure, it was observed that the all emulsion samples had a less smoke opacity than the diesel fuel. This is the fact that the presence of water content in the emulsifier fuels will aid to reduce the smoke for its increased amount in oxygen in water structure. The smoke opacity decreased by 11.6, 22, 30.4 and $39 \%$ for the DW5, DW10, DW15 and DW20 respectively, compared to the diesel fuel. The emissions of $\mathrm{HC}$ for the emulsions fuel and pure diesel versus engine loads are illustrated in figure (4). Usually, the gases leaving the combustion chamber contains unburned hydrocarbons less than $100 \mathrm{ppm}$ as mentioned by Patel et al. (2017), which represent the amount of the fuel which didn't contribute to mechanical work. The unburned $\mathrm{HC}$ emissions will reduce the potential energy of the fuel, and it passed to the exhaust without contribution to the overall engine efficiency. From the figure, on feeding the emulsion DW5 with which contain the minimum amount of water as a fuel to the engine, a decrease in the amount of the emitted $\mathrm{HC}$ by $\sim 8.3 \%$ was observed. Unfortunately, on increasing the amount of water, the case will be reversed, i.e. the emitted HC will increase for the emulsions DW10, DW15 and DW20 by 2, 9.3 and $12.6 \%$ respectively. Although the combustion process is related to the oxygen availability, the temperature of the combustion chamber was reduced due to the formation steam arized from the presence of added additional water (more than $5 \%$ of the emulsion). The emission of $\mathrm{CO}$ gas behaves in similar way to that of $\mathrm{HC}$ emission as shown in figure (5), concerning the increase in the loads, i.e. generally it decrease for all the used fuels. This behavior can be attributed to efficient combustion due to the availability of more oxygen from water and air. The emulsion DW5 showed the lowest decrease in CO production, were decreased by $11 \%$ while DW10 emulsion is almost coincide to that of pure diesel fuel. But on increasing the amount of water in the emulsions DW15 and DW20, different story can be told, the presence of more water in the fuel will relatively lower temperature of combustion due the formation of more steam; consequently, the conversion of $\mathrm{CO}$ to $\mathrm{CO}_{2}$ will be lower at relatively lower temperature. Such process will relatively increase the emission of CO by 9 and $14.3 \%$ respectively, when compared to the pure diesel. Energy is obtained from fossil fuels through combustion (burning) and refers to reaction of with oxygen (or air which contain $20 \%$ oxygen) to create carbon dioxide $\mathrm{CO}_{2}$, water, and heat Hegde et al. (2016). The efficient combustion will produce larger amount of $\mathrm{CO}_{2}$, in other words the increase in the amount of emitted $\mathrm{CO}_{2}$ is a good indication for the efficiency of the combustion inside the engine cylinder. figure (6) showed the combustion process observed for the diesel and diesel-water emulsion fuels used in this work. Generally, it apparent that on increasing the amount of water in the used fuel emulsions is accompanied with related increase in the emitted amount of $\mathrm{CO}_{2}$. On increasing the loads, the production of $\mathrm{CO}_{2}$ was increased by $4,8.7,12$ and $14.3 \%$ for DW5, DW10, DW15 and DW20, respectively. It is possible to state that the increase in water content of these fuel emulsions will aid the efficiency of combustion significantly. Increased combustion efficiency will be reflected as the decrease in CO content (as shown in figure (5)) and corresponding increase of $\mathrm{CO}_{2}$ level (as shown in figure (6)). 


\section{CONCLUSIONS}

Single cylinder 4-stroke direct injection CI engine was used to conduct experiments needed to judge the best emulsions prepared from diesel fuel with various water content. The $\mathrm{NO}_{\mathrm{X}}$, smoke, $\mathrm{HC}, \mathrm{CO}$ and $\mathrm{CO}_{2}$ emissions were recorded at different loads, and the results were discussed.

1. The emissions of $\mathrm{CO}_{2}$ for all emulsion samples were found to be higher than that of diesel fuel.

2. The emissions of $\mathrm{NO}_{\mathrm{X}}$ were found to be less by $11.1,17.67,25.8$ and $32.5 \%$ for the DW5, DW10, DW15 and DW20, respectively.

3. The smoke opacity decreased on increasing water content for the above emulsions, were less by $11.6,22,30.4$ and $39 \%$ respectively.

4. The HC emissions were found to be less by $8.3 \%$ for DW5 compared to the pure diesel, but on increasing water content, the $\mathrm{HC}$ emissions were increased by 2, 9.3 and $12.6 \%$ for DW10, DW15 and DW20, respectively.

5. CO emissions with low water content were less or almost equal with the pure diesel fuel. However it was found that the increase in water content up to $10 \%$ will increase $\mathrm{CO}$ emissions. This is the result of incomplete combustion process of the fuel at high temperatures inside cylinder.

6. Generally, using $20 \%$ (by water content) in the emulsion fuel was found to be an effective method to reduce the emissions of $\mathrm{NO}_{\mathrm{X}}$ and smoke in $\mathrm{CI}$ engine without any modifications to it, in concern with the environmental pollution.

Table (1): Emulsified fuel specifications.

\begin{tabular}{|c|c|c|c|c|}
\hline $\begin{array}{c}\text { Fuel } \\
\text { Type }\end{array}$ & $\begin{array}{c}\text { Diesel } \\
(\boldsymbol{\%})\end{array}$ & $\begin{array}{c}\text { Water } \\
(\boldsymbol{\%})\end{array}$ & $\begin{array}{c}\text { Tween 20 (\%) } \\
\text { (Surfactant) }\end{array}$ & $\begin{array}{c}\text { Oleic Acid (\%) } \\
\text { (Surfactant) }\end{array}$ \\
\hline DW5 & 94 & 5 & 0.5 & 0.5 \\
\hline DW10 & 89 & 10 & 0.5 & 0.5 \\
\hline DW15 & 84 & 15 & 0.5 & 0.5 \\
\hline DW20 & 79 & 20 & 0.5 & 0.5 \\
\hline
\end{tabular}

Table (2): Physical properties of all tested fuels.

\begin{tabular}{|c|c|c|c|c|c|}
\hline \multicolumn{1}{|c|}{ Property } & Diesel & DW5 & DW10 & DW15 & DW20 \\
\hline Density @ $\mathbf{1 5}{ }^{\circ} \mathbf{C}, \quad \mathbf{~ k g / \mathbf { m } ^ { \mathbf { 3 } }}$ & 829 & 836 & 844 & 851 & 860 \\
\hline Calorific value, $\quad \mathbf{k J} / \mathbf{k g}$ & 42850 & 41370 & 40240 & 39080 & 37820 \\
\hline Kinematic viscosity @ $\mathbf{2 0}{ }^{\circ} \mathbf{C} \mathbf{~} \mathbf{~ m m}^{2} / \mathbf{s}$ & 2.71 & 3.14 & 3.33 & 3.62 & 4.80 \\
\hline
\end{tabular}


Table (3): Engine specifications.

\begin{tabular}{|l|l|}
\hline Engine Model & Kirloskar \\
\hline Type & $\begin{array}{l}\text { Single cylinder, 4-Stroke, Compression Ignition } \\
\text { Engine }\end{array}$ \\
\hline Type of Cooling & Water-Cooled \\
\hline System of Injection & Direct Injection \\
\hline Stroke & $110 \mathrm{~mm}$ \\
\hline Bore & $80 \mathrm{~mm}$ \\
\hline Engine Speed & $1500 \mathrm{rpm}$ \\
\hline Compression Ratio & $17: 1$ \\
\hline Rated Power & $3.7 \mathrm{~kW}(5 \mathrm{HP})$ \\
\hline Dynamometer & rope brake dynamometer \\
\hline
\end{tabular}

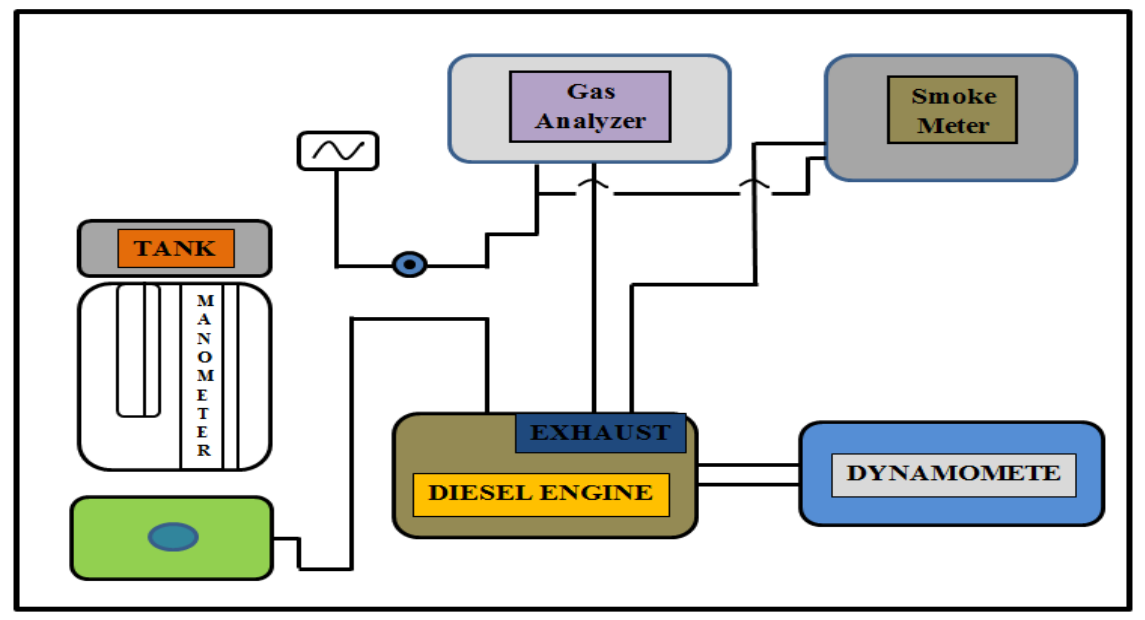

Fig. (1): Schematic Diagram of the Experimental Setup used in this work.

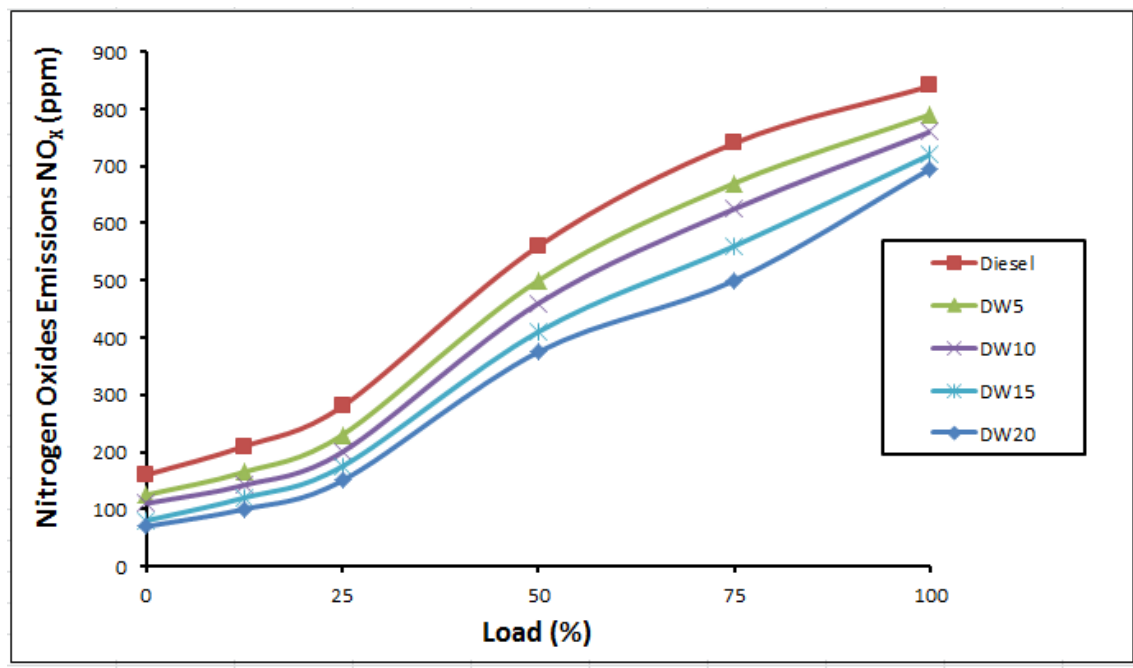

Fig. (2): The NOx emissions of DW5, DW10, DW15, DW20 and pure diesel versus load. 


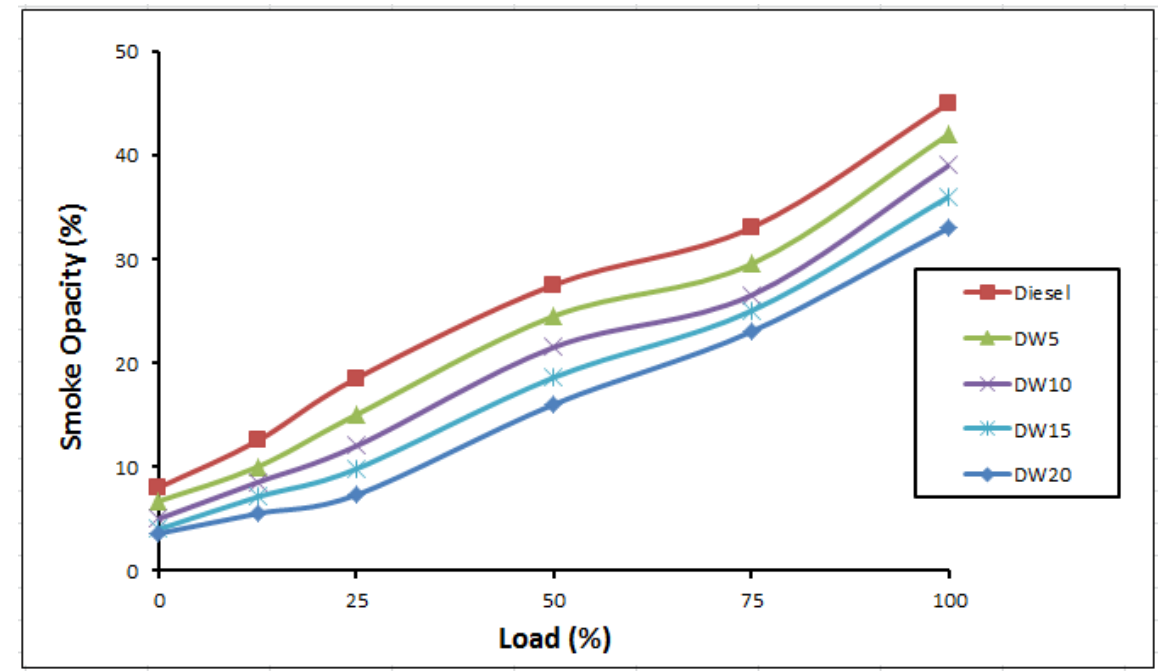

Fig. (3): The smoke opacity of DW5, DW10, DW15, DW20 and diesel fuel versus load.

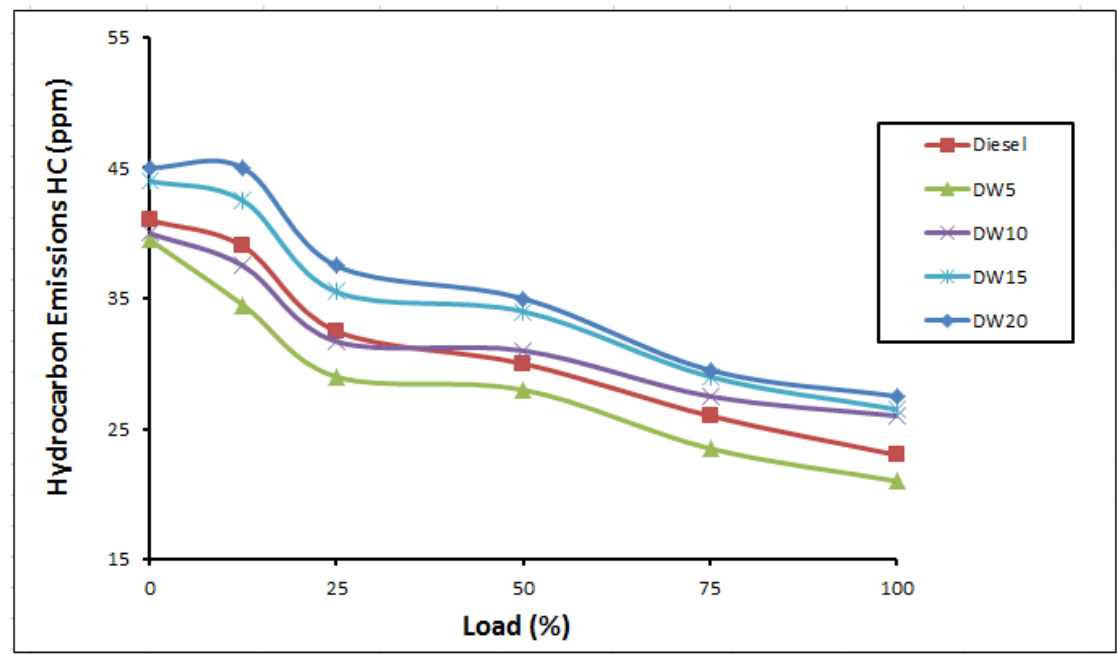

Fig. (4): The HC emissions of DW5, DW10, DW15, DW20 and diesel fuel versus load.

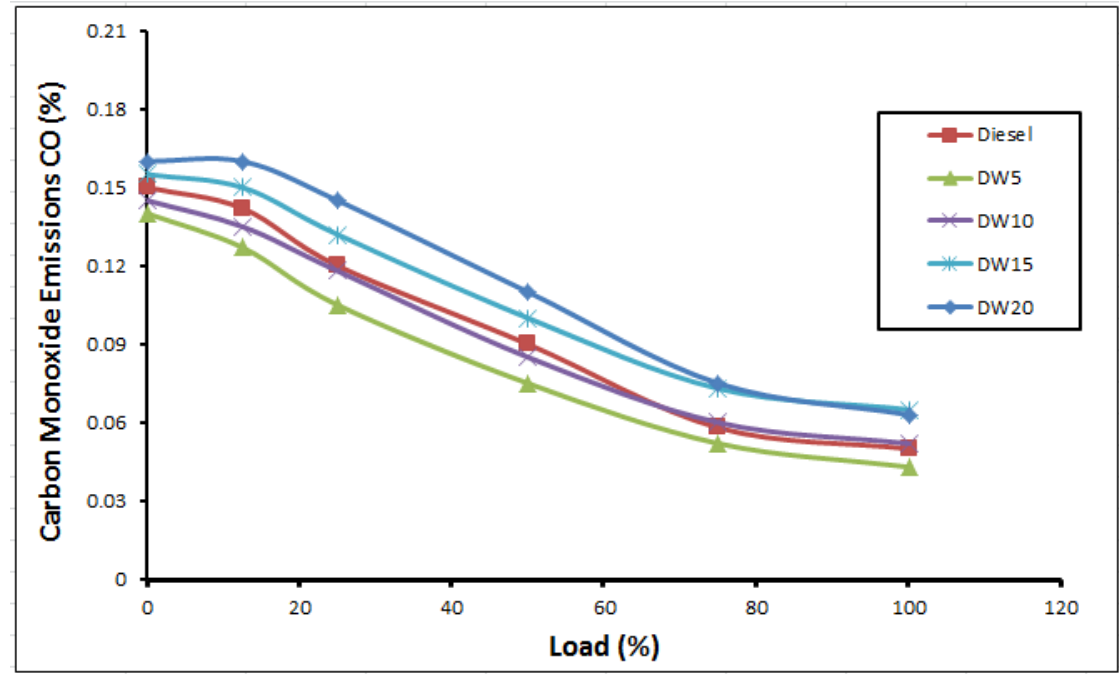

Fig. (5): The CO emissions of DW5, DW10, DW15, DW20 and diesel fuel versus load. 


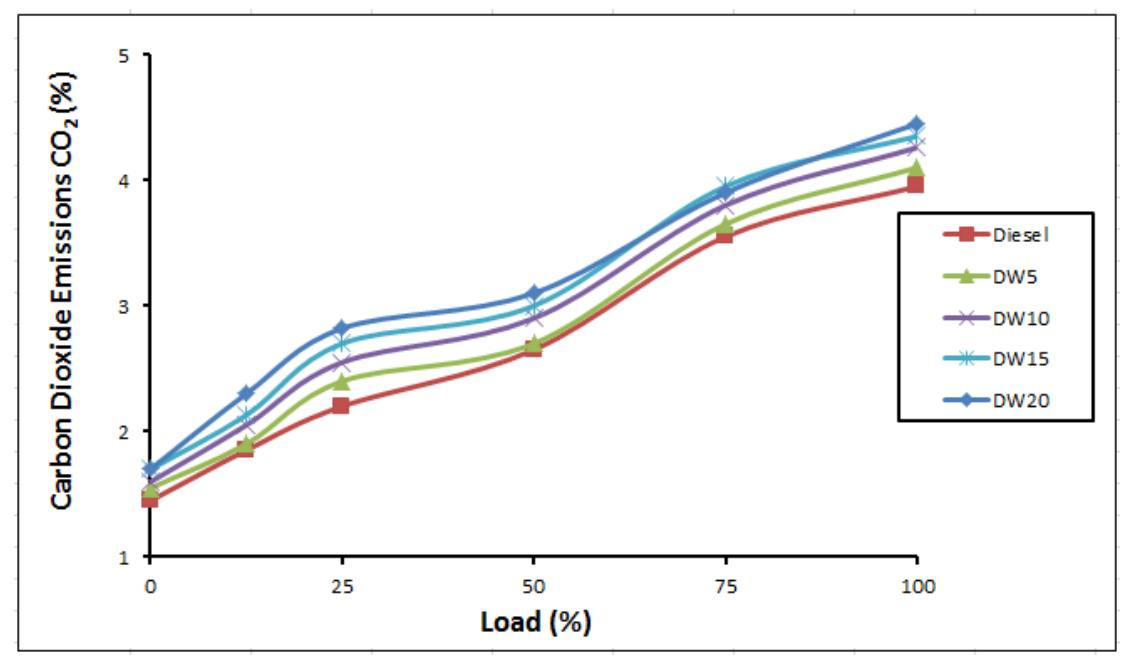

Fig. (6): The $\mathrm{CO}_{2}$ emissions of DW5, DW10, DW15, DW20 and diesel fuel versus load.

\section{REFERENCES}

Abdulrahman Shakir Mahmood, Haqi I. Qatta, Saadi M. D. Al-Nuzal, and Talib Kamil Abed, "Characteristics of exhaust emissions for a diesel engine fuelled by corn oil biodiesel and blended with diesel fuel", Engineering and Technology Journal, (Accepted for publication), 2019.

Alahmer, A., Yamin, J., Sakhrieh, A. and Hamdan, M. A., "Engine performance using emulsified diesel fuel", Energy Conversion and Management, Vol. 51, No. 8, pp.1708-1713, 2010 .

Dibofori-Orji, A.N., "Critical processes involved in formulation of water-in-oil fuel emulsions, combustion efficiency of the emulsified fuels and their possible environmental impacts", Research Journal of Applied Sciences, Engineering and Technology, Vol. 3, No. 8, pp.701-706, 2011.

Dubey, M. and Saxena, V., "Impact of Emulsified Water/Diesel Mixture on Engine Performance and Environment", International Journal of Engineering Trends and Technology (IJETT), Vol. 36, No. 9, pp. 461-466, 2016.

Hasannuddin, A. K., Ahmad, M. I., Zahari, M., Mohd, S. S., Aiman, A. B., Aizam, S. A., and Wira, J. Y., "Stability Studies of Water-in-Diesel Emulsion", In Applied Mechanics and Materials, Vol. 663, pp. 54-57, Trans Tech Publications, 2014.

Hegde, R. R., Sharma, P., Raj, P., Keny, R. V., Bhide, P. J., Kumar, S., Bhattacharya, S. S., Lohani, A., Kumar, A., Verma, A. and Chakraborty, P., "Factors affecting emissions from diesel fuel and water-in-diesel emulsion", Energy Sources, Part A: Recovery, Utilization, and Environmental Effects, Vol. 38, No. 12, pp.1771-1778, 2016.

Ithnin, A. M., Noge, H., Kadir, H. A. and Jazair, W., "An overview of utilizing water-in-diesel emulsion fuel in diesel engine and its potential research study", Journal of the Energy Institute, Vol. 87, No. 4, pp.273-288, 2014. 
Jiaqiang, E., Zuo, W., Gao, J., Peng, Q., Zhang, Z., and Hieu, P. M., "Effect analysis on pressure drop of the continuous regeneration-diesel particulate filter based on $\mathrm{NO}_{2}$ assisted regeneration", Applied Thermal Engineering, Vol. 100, pp. 356-366, 2016.

Kannan, G. R. and Anand, R., "Experimental investigation on diesel engine with diestrolwater micro emulsions", Energy, Vol. 36, No. 3, pp.1680-1687, 2011.

Lin, S. L., Lee, W. J., Chang, S. S., Lee, C. F., Lee, L. F., Lin, C. S. and Loong, H., "Energy savings and emission reduction of traditional pollutants, particulate matter, and polycyclic aromatic hydrocarbon using solvent-containing water emulsified heavy fuel oil in boilers", Energy and Fuels, Vol. 25, No. 4, pp.1537-1546, 2011.

Marchitto, L., Calabria, R., Tornatore, C., Bellettre, J., Massoli, P., Montillet, A., and Valentino, G., "Optical investigations in a CI engine fueled with water in diesel emulsion produced through microchannels", Experimental Thermal and Fluid Science, Vol. 95, pp. 96$103,2018$.

Mondal, P. K., and Mandal, B. K., "A comprehensive review on the feasibility of using water emulsified diesel as a CI engine fuel”, Fuel, Vol. 237, pp. 937-960, 2019.

Ochoterena, R., Lif, A., Nydén, M., Andersson, S. and Denbratt, I., "Optical studies of spray development and combustion of water-in-diesel emulsion and micro emulsion fuels", Fuel, Vol. 89, No. 1, pp.122-132, 2010.

Patel, N. S., Modi, M. A., and Patel, T. M., "Investigation of CI Engine Emission using Emulsified Diesel Fuel", Journal of Mechanical and Civil Engineering (IOSR-JMCE), Vol. 14, No. 2, pp. 70-78, 2017.

Paul, A., Panua, R., and Debroy, D., "An experimental study of combustion, performance, exergy and emission characteristics of a CI engine fueled by Diesel-ethanol-biodiesel blends", Energy, Vol. 141, pp. 839-852, 2017.

Şahin, Z., Tuti, M., and Durgun, O., "Experimental investigation of the effects of water adding to the intake air on the engine performance and exhaust emissions in a DI automotive diesel engine", Fuel, Vol. 115, pp. 884-895, 2014.

Salih, S. Y., "Water - Diesel Emulsion: A review", International Journal of Advances in Engineering and Technology, Vol. 10, No. 3, pp. 429-436, 2017.

Scarpete, D., Krause, H. and Gheorghe, M., "Effect of water content in diesel-water emulsified fuel on diesel engine performance", International Scientific-Technical Conference Trans \& MOTAUTO 13, Vol. 1, pp. 25-28, 2013.

Seifi, M. R., Hassan-Beygi, S. R., Ghobadian, B., Desideri, U. and Antonelli, M., "Experimental investigation of a diesel engine power, torque and noise emission using waterdiesel emulsions", Fuel, Vol. 166, pp.392-399, 2016. 
Syu, J. Y., Chang, Y. Y., Tseng, C. H., Yan, Y. L., Chang, Y. M., Chen, C. C. and Lin, W. Y., "Effects of water-emulsified fuel on a diesel engine generator's thermal efficiency and exhaust", Journal of the Air \& Waste Management Association, Vol. 64, No. 8, pp.970-978, 2014. 